УДК $631.147 \ll 71 »: 338.432$

(C) 2015

Мінькова О. Г., аспірант

(науковий керівник - доктор сільськогосподарських наук А. В. Калініченко)

Полтавська державна аграрна академія

\title{
ЕВОЛЮЦЯ ПОНЯТТЯ ЕКОЛОГІЧНОСТІ ГОСПОДАРЮВАННЯ В АГРАРНОМУ ВИРОБНИЦТВІ
}

\section{Рецензент - доктор сільськогосподарських наук, професор П. В. Писаренко}

У статті визначено основні передумови зародження екологічного господарства та узагальнено напрями екологічного спрямування аграрного виробництва. Проаналізовано етапи становлення поняття екологічності господарювання у вітчизняній та закордонній теорії і практиці. Проведено огляд літературних джерел шьодо їх сутності та науково-теоретичні тендениії розвитку. Наведено підходи до класифікаиії агроекологічних моделей виробництва та їх відмінності. Розглянуто існуючі альтернативні методи ведення сільськогосподарської діяльності.

Ключові слова: екологічність господарювання, способи (напрями, моделі) ведення сільськогосподарського виробництва, альтернативні системи землеробства.

Постановка проблеми. Доцільність проведення комплексних наукових досліджень шляхів i способів забезпечення екологічного спрямування стратегій господарювання на аграрних підприємствах України обумовлюються необхідністю нормативного визначення таких понять, як «екологічність господарювання», «екологічна продукція», «екологічність підприємства» тощо. На відміну від значної кількості інших країн світу, в нашій державі практично не існує прийнятого на офіційному чи правовому рівні чіткого трактування таких категорій, як екологічне чи екологічно-безпечне сільськогосподарське виробництво й т. п.

На сьогоднішній день в Україні втілюється чимало різноманітних стратегій розвитку як аграрної, так і екологічної політики, засадами яких $\epsilon$ створення умов для широкого впровадження екологічно орієнтованих і органічних технологій ведення сільського господарства.

Але систематичне визначення їх кількості, рівня впровадження екологічних напрямів господарювання, здійснення їх моніторингу в агропромисловому комплексі практично не проводиться. Саме тому для виявлення ступеня екологічності господарств $є$ необхідно умовою створення ефективної науково-методологічної бази, яка б надавала правове та організаційне підгрунтя.
Аналіз останніх досліджень і публікацій, у яких започатковано розв'язання проблеми. У світовій практиці розуміння теоретичних засад альтернативного землеробства значною мірою окреслилося і процес перейшов у фазу активного втілення. Відмітимо також потужний вклад вітчизняних вчених. Так, праці С. С. Антонця, А. С. Антонця, В. М. Писаренка присвячені дослідженню біологізації та практичному впровадженню органічного землеробства [19]; П. В. Писаренка, О. О. Горба, Т. В. Невмиваки, Ю. С. Голіка - основам біологічного та адаптивного землеробства [20]; М. В. Зубця, В. В. Медведєва, С. А. Балюка - особливостям консервативного землеробства [12]; С. М. Вегери - концептуальним підходам натурального землеробства [4]; Ю. П. Манька - ефективності систем екологічного землеробства [18]; Н. Х. Грабака - збалансованому господарству [5].

Зокрема, передумови зародження органічного землеробства та його функціонування закладено у наукових працях М. В. Капштика та М. К. Шикули [6], розвиток і наукове забезпечення його в Європейських країнах продовжував досліджувати М. В. Зубець [12], проблеми та перспективи В. В. Скальський [22], органічний рух в Україні - Є. В. Милованов [17], а тенденції розвитку виробництва органічної продукції - Т. О. Чайка.

Варто зазначити, що доцільність впровадження екологічних напрямів землеробства та його перспективу підкреслив Н. Х. Грабак [5], теоретичні основи екологічного господарювання продовжували висвітлювати В. В. Підліснюк [9], Ю. П. Манько [18], В. В. Таргоня [25] та ін. Вагомий внесок в екологічність агровиробництва в Україні здійснили Ю. І. Старчевський [7] i В. В. Тарасова. Але найбільшої уваги серед наукової спільноти приділено питанням екологізації виробництва, зокрема механізм екологізації продовольчого комплексу розробив Л. С. Купінець [14], а в життєвому циклі продукції - I. М. Бурлакова.

Проте, не зважаючи на значний внесок науковців, дискусійним залишається питання щодо 


\section{СТОРІНКА МОЛОДОГО ВЧЕНОГО}

способів визначення рівня екологічності господарств та їх критеріальної бази. Існуючі науковометодичні підходи розроблені недостатньо, що зумовлює актуальність досліджуваної проблеми.

Метою дослідження $\epsilon$ аналіз існуючих напрямів ведення альтернативного землеробства, теоретичного та практичного втілення його основних засад в Україні, а також підходів до визначення екологічності господарювання.

Завдання досліджень: систематизація теоретично-понятійного апарату екологічного господарювання, виявлення термінологічних відмінностей між існуючими категоріями.

Матеріали і методи досліджень. Матеріалами досліджень $є$ літературні джерела, які об'єднують наукові праці, статті, монографії, звіти науково-дослідних робіт та автореферати. У досліджені використані загальнонаукові теоретичні методи аналізу та синтезу, індукції та дедукції, а також застосовані історичний та логічний методи.

Результати досліджень. Екологічність регіону в найбільшій мірі має визначати наявність сільськогосподарських підприємств, що ведуть господарську діяльність у напрямку їх екологізації.

Незалежно від форм власності та організаційноправових форм, сільськогосподарське (аграрне) підприємство - це суб'єкт господарювання, який має статус юридичної особи і здійснює виробничу сільськогосподарську діяльність 3 метою отримання прибутку. Основним засобом у таких підприємствах, як правило, є земельні ресурси, а їх ефективне використання залежить від системи землеробства. В усьому світі у процесі впровадження та розвитку тих чи інших систем землеробства можна виділити дві основні моделі інтенсивну та екстенсивну.

Інтенсивні моделі характеризуються збільшенням урожайності сільськогосподарських культур за рахунок підвищення витрат праці та капіталовкладень у механізацію, використання засобів захисту рослин, добрив, системи зрошення тощо. Мірою інтенсивності є норми внесення азоту [20]. Досить часто інтенсивні моделі класифікують як традиційні, але у різні періоди й у різних країнах слід відзначити значні розбіжності у класифікації та термінології.

Можна констатувати, що станом на сьогодні модель інтенсивної хімізації сільського господарства вичерпала себе у розвинутих країнах. Причиною цього стало як значне погіршення стану грунтового покриву, так і невідворотні зміни, що відбуваються у гідросфері. Водночас інтенсивні технології у більшості своїй є енерго-, капіталомісткими, що потребують великих субсидій, без яких виробництво стає збитковим [16].

Bce частіше 3'являлися передумови для введення науково-обгрунтованих норм хімізації та активного землевикористання. Так, після ілюзорного прогресу впровадження світової стратегії природокористування, створеної в 1945 р. Продовольчою сільськогосподарською організацією $\mathrm{OOH}$ (FAO), що полягала в інтенсифікації галузі, коли країни орієнтувалися на монокультури, тісно пов'язували свою діяльність із хімічною індустрією, вели політику заохочувального поширення пестицидів та синтетичних міндобрив, 3 1985 р. ЄС розпочав нову політику розвитку сільського господарства, тобто екологічну конверсію [11]. Для уникнення негативних наслідків надмірної інтенсифікації в індустріально розвинених країнах значно скоротилися обсяги застосування мінеральних добрив і хімічних засобів захисту рослин. Натомість збільшилося використання біологічних способів захисту агробіоценозів [16].

Так, наприклад, вітчизняний економіст В. Г. Андрійчук, надаючи перевагу інтенсивному типу відтворення, запропонував введення обов'язкового екологічно допустимого рівня інтенсифікації, тобто граничну межу використання, перехід за яку негативно впливає на агроекосистему. Він вважав, що підприємства, формуючи інтенсивний тип розвитку, повинні забезпечити й наявність окремих елементів екологізації [1].

До основних ознак екологічності підприємства він відносив:

- забезпечення розширеного відтворення родючості грунту, яке супроводжується збереженням і підвищенням вмісту в ньому гумусу і забезпеченням оптимального рівня розораності земельних угідь;

- виробництво екологічно чистої продукції, недопущення перевищення встановлених рівнів iï забрудненості;

- додержання встановлених правил транспортування, зберігання і застосування засобів захисту рослин, стимуляторів їх росту, мінеральних добрив $з$ тим, щоб не допустити забруднення ними навколишнього природного середовища i продуктів харчування;

- недопущення порушень екологічної безпеки і забезпечення відтворення повітря й води;

- максимальне використання природних засобів боротьби із шкідниками та хворобами сільськогосподарських культур і тварин, а також 3 бур'янами;

- недопущення порушень екологічних вимог під час проектування, розміщення і будівництва, 


\section{СТОРІНКА МОЛОДОГО ВЧЕНОГО}

реконструкції і введенні в дію нових будівель та споруд, насамперед тваринницьких комплексів, меліоративних систем.

Нові системи отримали назву альтернативних, хоча суть цього поняття в різних країнах значним чином відрізняється [16]. У більшості країн світу, в тому числі й на Україні, під альтернативним землеробством розуміють систему методів, в якій під час організації виробництва сільськогосподарської продукції надається перевага екологічним закономірностям у порівнянні до традиційних форм господарювання [19]. Назви систем землеробства науковці досить часто пов'язують 3 назвами іiі елементів, що відрізняються своїм змістом (застосуванням в системі удобрення лише органічних матеріалів, у системі захисту рослин - виключно біологічних засобів), вибором строків сівби сільськогосподарських культур за астрономічним календарем, адаптацією цілої системи до конкретних ландшафтів та інше [19].

Серед назв (термінів), що характеризують способи чи найпоширеніші напрями ведення альтернативного землеробства $є$ : біодинамічне, органічне, біологічне, органічно-біологічне, екологічне, біоінтенсивне міні-землеробство, маловитратне стале землеробство, технології використання ефективних мікроорганізмів або ЕМтехнології, природне землеробство та інше $[4,5$, 7-9, 17-20, 40, 11].

Короткий аналіз появи та специфіки використання у світі наведеної вище термінології дає змогу виділити наступні ключові моменти їі розвитку, які $є$ характерними як для європейської спільноти, так і наукової думки американських вчених.

Група дослідників 3 питань впровадження органічного землеробства Департаменту сільського господарства США (United States Department of Agriculture) у 1980 році запропонувала таке визначення: «Органічне землеробство - це система виробництва сільськогосподарської продукції, яка забороняє або в значній мірі обмежує використання синтетичних комбінованих добрив, пестицидів, регуляторів росту та харчових добавок до кормів під час відгодівлі тварин. Така система по можливості максимально базується на сівозмінах, використанні рослинних решток, гною та компостів, бобових рослин та рослинних добрив, органічних відходів виробництва, мінеральної сировини, механічному обробітку грунтів та біологічних засобах боротьби зі шкідниками 3 метою підвищення родючості та покращання структури грунтів, забезпечення повноцінного живлення рослин та боротьби 3 бур'янами та різноманітними шкідниками» [17].

Пізніше, у квітні 1995 року, Колегія з національних стандартів органічної продукції USDA запропонувала дещо інше визначення: «Органічне землеробство - це система екологічного менеджменту сільськогосподарського виробництва, яка підтримує та покращує біорізноманіття, біологічні цикли та біологічну активність грунтів» [23].

Визначення Міжнародної федерації сільськогосподарського органічного руху робить дещо інший акцент, а саме на антропогенний фактор. За ним органічне сільське господарство - це виробнича система, яка підтримує здоров'я грунтів, екосистем і людей. Вона спирається на екологічні процеси, біорізноманіття і цикли, адаптовані до місцевих умов, а не на необмежене використання ресурсів 3 негативними побічними ефектами. Органічне сільське господарство мусить поєднувати традиції, інновації і науку в інтересах навколишнього середовища, сприяючи цим самим справедливим відносинам і гарній якості життя для всіх зацікавлених сторін [1].

Органічно-біологічне землеробство започатковано в Швейцарії у 1940 році. Воно передбачає уникнення застосування мінеральних добрив, пестицидів та інших препаратів. Основою $є$ сівозміна, родючість грунту підтримується за рахунок органічних добрив, а для знищення бур'янів застосовують механічні та термічні засоби [9]. 3 погляду агроекології це найбільш продумана система, яка дає змогу контролювати природність кругообігів речовин в агроекосистемах кожного окремого господарства. Біологізація виробництва в цій системі досягається шляхом максимальної стимуляції діяльності грунтової мікрофлори [11].

Термін «органічне землеробство» офіційно прийнятий в англомовних країнах ЄС. Еквівалентним терміном у Франції, Італії, Португалії та країнах Бенілюксу є «біологічне землеробство», а в Данії та Німеччині та іспаномовних країнах «екологічне землеробство». У додатку XI Регламенту комісії (СС) № 889/2008 від 5 вересня 2008 р. «Детальні правила щодо органічного виробництва, маркування і контролю для впровадження Постанови Ради (СС) № 834/2007 стосовно органічного виробництва i маркування органічних продуктів» визначені різні терміни органічного землеробства для низки країн [17]. До них можна віднести й Україну у зв'язку із прийняттям Закону України від 3 вересня 2013 р. № 425-VII «Про виробництво та обіг органічної сільськогосподарської продукції та сировини».

Деякі науковці вважають, що найбільш адек- 


\section{СТОРІНКА МОЛОДОГО ВЧЕНОГО}

ватним щодо суті можна вважати визначення органічного землеробства як системи сільськогосподарського менеджменту агроекосистем, що грунтується на максимальному використанні біологічних факторів підвищення родючості грунтів, агротехнологічних заходів захисту рослин, а також на виконанні комплексу інших заходів, які забезпечують екологічно-, соціально- та економічно доцільне виробництво сільськогосподарської продукції й сировини [23].

Ще одним із розповсюджених напрямів ведення аграрного виробництва в країнах Європи $\epsilon$ консервативне землеробство. Його особливості детально викладені у працях Зубця М. В., Медведєва В. В., Балюка С. А. [12]. Консервативне землеробство - технології (обробітку, удобрення, меліорації) вирощування культур, спрямовані на максимально можливе збереження біорізноманіття, складу й властивостей грунтів, захист від деградації (ерозіі, втрат гумусу, переущільнення та ін.). У значній частині країн Європи органічне землеробство розглядається як складова частина консервативного землеробства [12].

До альтернативного землеробства прихильники цього напряму $[20,11]$ відносять й так зване компромісне землеробство, що відповідає концепції отримання екологічно чистих продуктів в екологічно безвідходному виробництві. Розробка компромісного землеробства відбувалася приблизно з кінця XVIII століття одночасно в країнах Західної Європи та Росії. Ідея компромісу полягала у включенні до використовуваних засобів впливу на поле та сільськогосподарські рослини таких засобів, які разом з максимізацією виходу продукції запобігали чи хоча б сповільнювали темпи втрати ріллею головної споживчої якості - родючості грунту і не призводили б до деградації природного середовища в агросфері [11].

Одним із варіантів компромісного землеробства є система адаптивного рослинництва, розроблена Жученком О. О. Адаптивне рослинництво це сукупність індустріальних сільськогосподарських систем $з$ високою продуктивністю, що відповідає природним умовам і не порушує екологічної рівноваги. Таке землеробство має скорочене використання мінеральних добрив та спирається на адаптивні сорти [11].

Останнім часом набуває актуальності поняття екологічного землеробства, але на сьогодні не достатньо обгрунтовано теоретико-методологічний фундамент зазначеного напряму.

У цілому на підставі зазначеного вище можна стверджувати, що світова наукова думка акцентує увагу на тому, що, яка б із вище наведених систем землеробства не застосовувалась у гос- подарстві, у порівнянні з інтенсивною ії можна називати екологічною. Але у різних країнах існують певні термінологічні відмінності під час визначення поняття екологічного землеробства або виробництва, що часом призводять до складностей у перекладі міжнародних документів, їх розуміння та взаємоузгодження.

Що стосується вітчизняних тенденцій розвитку теоретично-понятійного апарату екологізації аграрної сфери та шляхів практичного втілення iii основних засад, то можна виділити такі основні напрями землеробства: органічне, натуральне, біологічне та екологічне (або екологічно спрямоване).

Але слід звернути увагу, що одним із основних факторів чи критеріїв вибору стратегії розвитку є організаційна форма та фінансовий стан підприємства. Адже саме для України дуже часто характерною ознакою виступає так звана «вимушена екологічність», яка не має нічого спільного із бажанням виробляти продукцію високої якості, а фактично демонструє обмеженість ресурсів для закупівлі добрив чи засобів захисту.

У 2009 р. $з$ відповідним поглибленим аналізом С. М. Вегера ввів в Україні термін «натуральне землеробство», ефективність якого грунтується на використанні не лише органіки, а й природних регулюючих механізмів, тобто біологічних видів. Під виробництвом натуральної (органічної) фітопродукції С. М. Вегера розумів цілісну систему формування та функціонування фітоценозів господарств, яка повинна включити низку основних ланок, зокрема організаційно-правову, сертифікацію на основі міжнародних стандартів, вирощування сировини, іiі зберігання, транспортування, зберігання, переробку та отримання якісної й безпечної продукції, реалізацію продукції на персоніфікованих ринках, споживання тощо [4].

Досить часто у вітчизняній літературі зустрічається термін природне землеробство, що має багато спільного 3 органічним, оскільки родючість грунту пропонується підтримувати за рахунок використання компостів та застосування мікробіологічних добрив [9].

Отже, можна зазначити, що загальноприйнятою є ідея, що системи біологічного, органічного землеробства $є$ одним 3 найвищих ступенів екологізації аграрної галузі. Вони передбачають повне вилучення технології вирощування культур iз застосуванням агрохімікатів, замінюючи їх ресурсне забезпечення природними, органічними засобами. Масштаби можливого впровадження і освоєння біологічного землеробства во- 


\section{СТОРІНКА МОЛОДОГО ВЧЕНОГО}

чевидь визначає практика, і перш за все, виробництво органічних добрив і біологічних засобів захисту посівів від шкідливих організмів. У зв'язку з цим реальним варіантом системи землеробства в напрямі iї екологізації є модель екологічного землеробства 3 пріоритетним забезпеченням біокліматично і економічно обгрунтованої урожайності за рахунок екологічно обгрунтованої кількості промислових засобів [18].

Згідно з проектом ДСТУ «Біоземлеробство. Основні поняття. Терміни та визначення» біологічне землеробство (екологічне, органічне землеробство) - вид інтегрованого землеробства, в якому сільськогосподарську продукцію отримують в результаті використання лише природних матеріалів і процесів та посилено вимоги до застосування агрохімікатів. У проекті розрізняють також біодинамічне землеробство - вид інтегрованого землеробства, в якому основний акцент зроблено на темпоральні закономірності онтогенезу рослин та впливу на нього деяких періодичних процесів у довкіллі [8].

Найбільш вживаними термінами чи напрямами наукового обгрунтування використовуваних систем землеробства $\epsilon$ «екологічне» або «екологічно спрямоване» землеробство.

За М. В. Капштиком екологічне землеробство - це розробка всіляких концепцій, у складі технологій рослинництва і тваринництва, спрямованих на поліпшення екологічного стану об'єктів сільського господарства [19]. У свою чергу, Ю. А. Злобін та Н. В. Кочубей вважають, що цей напрям складає аморфну групу технологій та ідей, які передбачають ті чи інші засоби екологізації землеробства [11].

Пріоритетами в екологічній системі землеробства мають бути оптимізація внесення органічних добрив $з$ використанням для цього їх можливих ресурсів: гною, компостів, нетоварної частини біологічного урожаю вирощуваних культур, маси сидеральних посівів; грунтозахисна система обробітку грунту; екологічно обгрунтована система захисту рослин від шкідливих організмів. Водночас екологічна система землеробства не протиставляє природні ресурси антропогенним, але робить галузь природовідповідною, симбіотичною, вигідною і для людини, і для природи [24].

В екологічному землеробстві $є$ можливим використання мінеральних добрив, але вони мають бути виключно природного походження і до того ж не бути переробленими з використанням промислових методів. Дозволено використання фосфорних і калійних мінералів у випадку, коли в грунтах виявлено їх постійну нестачу [9].
Зокрема Таргоня В. [25] під альтернативним екологічним землеробством вважає систему агротехнічних заходів, яка, на відміну від традиційної, опирається на екологічні закономірності організації сільгоспвиробництва. Водночас в такому землеробстві немає суворих заборон, головне - одержати екологічно чисту продукцію. Воно $є$ складовою усього сільськогосподарського виробництва, для якого характерним $\epsilon$ використання біоконверсних комплексів - систем господарювання, за яких виробництво сільгосппродукції організовано із застосуванням максимально біологічних методів, 3 повною біоконверсією, переробленням і використанням усіх відходів цієї системи. Завдання комплексів - підвищення урожайності, отримання екологічно чистої продукції, широке відтворення родючості грунтів, поліпшення стану довкілля й економічне використання ресурсів навколишнього середовища [25].

Дослідивши основні науково-дослідні та практичні підходи до формування та використання тих чи інших систем землеробства, що містять екологічно-спрямовані елементи, доцільно проаналізувати існуючі способи чи стратегії ведення сільськогосподарського виробництва в цілому, діяльність яких базується на впровадженні зазначених вище систем землеробства.

Цікавим є підхід до класифікації існуючих моделей Л. С. Купінець, згідно з якою альтернативні системи землеробства представляють собою багатофункціональну агроекологічну модель виробництва. Незначні відмінності притаманні інтегрованій системі та моделі стійкого сільськогосподарського виробництва, що допускають застосування мінеральних добрив і пестицидів в обмеженій кількості за постійного контролю якості отриманої продукції. Тим не менш, усі перераховані системи землеробства орієнтовані на екологізацію землеробства, виробництво 3 використанням низькозатратних технологій та інноваційних рекомендацій агроекології, агрохімії, селекції тощо [14].

Зовсім по-іншому узагальнює існуючі способи ведення аграрного виробництва О. Л. Попова, яка пропонує розрізняти екологічне (або органічне) сільське господарство та екологічно сприятливе, дружнє до природи сільське господарство. Екологічне сільське господарство здійснюється в жорсткій відповідності до вимог екологічного (органічного) агровиробництва і підлягає сертифікації. А екологічно сприятливе сільське господарство, яке має бути притаманним більшості сільгосппідприємств, застосовує інтегровані методи ведення господарства [21].

У результатах наукових досліджень $[5,13]$ 


\section{СТОРІНКА МОЛОДОГО ВЧЕНОГО}

вчені використовують і дещо подібний термін екологоспрямоване сільськогосподарське виробництво. Одні вважають, що таке виробництво має узгодити й гармонізувати економічні, екологічні та соціальні цілі в галузі сільського господарства [5]. Інші під ним розуміють господарську діяльність, кінцева мета якої (отримання прибутку) досягається через задоволення попиту на ринку продовольства і сировини за одночасного зменшення негативного впливу на довкілля та сприяння сталому розвитку сільських територій [13].

Крім того, О. В. Ковальова виділяє чотири напрями екологічного спрямування аграрного виробництва [13]:

1) освоєння низькозатратних систем виробництва, що передбачають зменшення обсягів використання залучених ззовні у процес виробництва ресурсів за рахунок максимізації використання внутрішньогосподарських;

2) розвиток органічного виробництва, що регламентується базовими стандартами Міжнародної федерації органічного сільськогосподарського руху, Стандартом Продовольчої та сільськогосподарської організації ООН та Всесвітньої організації охорони здоров'я - Кодекс аліментаpiyc, в Європейському Союзі - Директивами № 834/2007 від 28 червня 2007 р. та ін.;

3 ) встановлення правил ведення сільського господарства, що обмежують його негативний вплив на довкілля і не вимагають значних додаткових витрат на їх виконання (Кодекси Належної та Доброї сільськогосподарської практики);

4) поєднання технологій аграрного виробництва із середовищевідтворювальними заходами.

Два останні напрями мають на меті обмежити негативний вплив сільськогосподарської діяльності на довкілля, розвиток двох перших забезпечить також отримання економічного ефекту за рахунок зниження витрат на виробництво та реалізації сертифікованої продукції органічного виробництва за більш високими цінами, ніж продукція традиційного сільськогосподарського виробництва [13].

Під екологічним агровиробництвом Ю. І. Старчевський [7] розуміє такий спосіб господарювання, який має підтримувати ресурси загального користування та запобігає їх деградації, підтримуючи стан сталої агроекосистеми, а також здійснює збереження родючості грунту за рахунок кругообігу в природі органічної та неорганічної матерії. Водночас культурні рослини отримують поживні речовини в результаті діяльності грунтових мікроорганізмів.

На відміну від більш оптимістичних прогнозів фахівців аграрного сектору вітчизняні економісти вважають, що ріст екологічного виробництва у світі й значною мірою в Україні відбувається внаслідок двох причин: підвищення попиту на сертифіковану органічну продукцію в розвинених країнах та слаборозвинених країнах у зв'язку 3 відсутністю ресурсів для підвищення врожайності [15]. До того ж В. В. Скальський наголошує на важливому факторі, який став поштовхом в Україні до переходу на екологічне господарство, - постійний брак коштів на розвиток сільського господарства [22]. Таким чином, можна говорити про існування господарств 3 «вимушеною екологічністю», до яких відносяться в основному невеликі підприємства.

Для проведення аналізу наявного стану екологічності господарювання в Україні, необхідно мати чітке визначення на рівні нормативної бази, за якими ознаками господарство можна віднести до категорії екологічних та спосіб виявлення рівню його екологічності.

Термін «екологічність» найбільш вживаним $\epsilon$ в промисловому виробництві, хоча й на науковометодичному рівні має широке використання. Як правило, екологічність зустрічається як характеристика об'єкта або результат керування організацією стосовно іï екологічних аспектів, але, на жаль, як у законодавстві України, так і в нормативній базі відсутні чіткі ознаки чи критерії екологічності.

Так, М. Я. Бомба екологічність розглядає як ознаку біологічного землеробства, тобто «безпечний для довкілля та здоров'я людини вплив на грунт і сільськогосподарські культури» [3].

Існує також поняття «декларація екологічності» - це заява, що описує ефект впливу на навколишнє середовище під час видобування сировини, виробництва, розподілу або постачання, використання й утилізації продукції, а заяву про екологічність, складену без участі третьої сторони за наявності певної вигоди виробнику, імпортеру, продавцю чи іншій особі називають самодекларацією екологічності [10]. Трактування ж самої екологічності відсутнє.

Отже, становлення екологічного господарювання має довголітню історію та декілька основних причин його виникнення: погіршення стану довкілля, здоров'я населення та обмеженість ресурсів на підприємствах. У зв'язку з розвитком альтернативних напрямів ведення сільськогосподарської діяльності виникає необхідність визначення впливу іiі на навколишнє природне середовище, тобто виявлення рівня екологічності господарств, що відносяться до агропромислового комплексу України. 


\section{СТОРІНКА МОЛОДОГО ВЧЕНОГО}

Висновок. Дослідивши існуючі альтернативні системи землеробства у світовій та вітчизняній практиці, слід зазначити, що вони мають як певні відмінності, так і спільні ознаки, адже всі надають перевагу екологічним імперативам.

Тому застосування їх у виробничій діяльності аграрного підприємства безумовно підвищують екологічний рівень його господарювання, але мають різний вплив на навколишне природне середовище.

Крім того, проведений аналіз поняття екологіч-

\section{БІБЛІОГРАФІЯ}

1. Андрійчук В. Г. Економіка аграрних підприємств : підручник [2-е вид., доп. і перероб.] / В. Г. Андрійчук. - К. : КНЕУ, 2002. - 624 с.

2. Бомба М. Я. Сучасні тенденції розвитку світового землеробства / М. Я. Бомба // Вісник НАН України. - 2007. - №12. - С. 34-40.

3. Вигера С. М. Концептуальні підходи до виробництва якісної та безпечної фіто продукції в Україні / С. М. Вигера // Перспективи екологізації аграрного виробництва в Україні [текст] : зб. наук. праць / за заг. ред. Ю. О. Лупенка, О. В. Ходаківської. - К. : ННЦ «IAE», 2012. $182 \mathrm{c}$.

4. Грабак H. X. Екологічний напрям у землеробстві та його перспектива / Н. Х. Грабак // Наукові праці. Екологія. - Вип. 140. - Т. 152. C. 20-25.

5. Грунтозахисна біологічна система землеробства в Україні : монографія / [за ред. М. К. Шикули]. - К. : Оранта, 2000. -389 с.

6. Дослідити наукові засади формування екологічності, ефективності та розвитку виробництва сільськогосподарської продукції на основі моделювання технологічних процесів біологічного рослинництва та соціальних запитів [текст] : звіт про наук.-досл. роботу за 2006-2010 pp. (заключний), № держ. реєстрації 0107U009812/ Нац. акад. аграр. наук України, Інж.-технол. ін-т «Біотехніка»; кер. н.-д. р. Ю. Старчевський. - О. : [б. в.], 2010. -81 c.

7. ДСТУ (проект) Біоземлеробство. Основні поняття. Терміни та визначення // ITI «Біотехніка». - Одеса, 2007. - 36 с.

8. Екологічне сільське господарство: кроки назустріч. Крок перший: екологічне землеробство / [за ред. В. Підліснюк]. - К. : Видавничий центр НАУ, 2006. - 79 с.

9. Екологічне управління : підручник / [Шевчук В. Я., Саталкін Ю. М., Білявський Г. О. та ін.]. - К. : Либідь, 2004. - 432 с.

10. Злобін Ю. А. Загальна екологія : [навчальний посібник] / Ю. А. Злобін, Н. В. Кочубей. - ності сільськогосподарського виробництва свідчить про те, що існуючі дослідження в цьому напрямі $\epsilon$ досить розрізненими, а також не носять системного характеру й не дають узагальненого розуміння рівню екологічності конкретного аграрного підприємства.

Тому визначення основних норм, критеріїв та самої процедури сертифікації, аудиту, моніторингу за ознакою екологічності $є$ актуальною проблемою сьогодення.

Суми : ВТД «Університетська книга», 2003. $416 \mathrm{c}$.

11. Зубець М. В. Розвиток і наукове забезпечення органічного землеробства в Свропейських країнах / М. В. Зубець, В. В. Медведєв, С. А. Балюк // Вісник аграрної науки. - 2010. - №10. C. 5-8.

12. Ковальова О. В. Організація управління еколого-спрямованим сільськогосподарським виробництвом / О. В. Ковальова : автореф. дис. на здобуття наук. ступеня к.е.н. : спец. 08.00.03 «Економіка та управління національним господарством. ННЦ «Інститут аграрної економіки» УААН. - К., 2008. - $21 \mathrm{c}$.

13. Купинеи Л. Е. Экологизация продовольственного комплекса: теория, методология, механизмы. - Одесса : ИПРЭЭИ НАН Украины, 2010. - $712 \mathrm{c}$.

14. Лииур I. Перехід до органічного землеробства за допомогою фінансового сектору / I. Лицур, О. Панков // Аграрна економіка. - 2011. T. 4, №1-4 - C. 105-109.

15. Лысенко Е. Г. Экологизация сельского хозяйства и переход к устойчивому развитию : сб. науч. трудов / Е. Г. Лысенко. - М. : [б. в.], 2004. $-312 \mathrm{c}$.

16. Милованов С. М. Органічне сільське господарство: перспективи для України. Посібник українського хлібороба / Є. М. Милованов. 2009. - C. 257-260.

17. Модель системи екологічного землеробства в Лісостепу України. Методичні рекомендації для впровадження у виробництво. - К. : Аграрна освіта, 2008. - 36 с.

18. Органічне землеробство: 3 досвіду ПП «Агроекологія» Шишацького району Полтавської області. Практичні рекомендації / [Антонець С. С., Антонець А. С., Писаренко В. М. та ін.]. - Полтава : РВВ ПДАА, 2010. - 200 с.

19. Основи біологічного та адаптивного землеробства : навчальний посібник / [Писаренко П. В., Горб О. О., Невмивака Т. В., Голік Ю. С.]. - 
Полтава : видавництво «Оріана», 2009. - 312 с.

20. Попова О. Л. Екологізація виробництва як чинник ефективного розвитку вітчизняних сільгосппідприємств / Попова О. Л // Перспективи екологізації аграрного виробництва в Україні [текст] : зб. наук. праць ; за заг. ред. Ю. О. Лупенка, О. В. Ходаківської. - К. : ННЦ «IAЕ», 2012. $182 \mathrm{c}$.

21. Скальський В. В. Органічне землеробство: проблеми та перспективи / В. В. Скальський // Економіка АПК. - 2010. - №4. - С. 48-53.

22. Сокол Л. М. Екологічне (органічне) землеробство - складова сталого сільського господарства / Л. М. Сокол, Т. Р. Стефановська, В. В. Під- ліснюк // Екологічна безпека. - 2008. - № 3-4. C. $102-109$.

23. Танчик С. П. Методологія диференційованої класифікації сучасних систем землеробства в Україні / С. П. Танчик, Ю. П. Манько, А. І. Бабенко // Посібник українського хлібороба. - 2013. T. 1. - C. 85-88.

24. Таргоня $B$. Екологізація землеробства: концепція розвитку / В. Таргоня // Новини агротехніки. - 2007. - № 4. - С. 40-41.

25. The ifoam norms for organic production and processing. Version 2012 [Електронний ресурс]. Режим доступу : http://www.infonet-biovision. org/res/res/files/4228.ifoam_norms 2012.pdf. 